\title{
Methods of acetabular defect visualization in dysplastic hip arthritis
}

\author{
For citation: Bol', sustavy, pozvonočnik. 2019:9(3):205-211. doi: 10.22141/2224-1507.9.3.2019.178645
}

\begin{abstract}
Background. There is an opinion that according to the displacement of the femoral head, hip arthritis may be divided into central and superolateral forms; the latter is usually caused by the dysplastic changes of the hip joint. The extant classifications of the developmental dysplasia of the hip mostly describe either an acetabular contour or the cranial distance at which the femoral head becomes displaced. However, none of them takes into account dysplastic defects of the acetabulum or their influence on the results of the surgery. The purpose of the study was to evaluate the roentgen-anthropometric parameters of the dysplastic acetabulum and visualize the defects, affecting the outcomes of the total hip arthroplasty. Materials and methods. The roentgen-anthropometric analysis of 201 dysplastic hips and 70 normal hips acetabula was performed. We've studied the acetabular width, depth, thickness of the acetabular bottom, acetabular index and inclination and volume of the acetabular dysplastic defect. Statistical analysis included mean, relative values, median, quartiles, nonparametric Mann-Whitney and Kruskal-Wallis criterion with median-test, nonparametric Kendall correlation. The difference between values was considered significant if $p<0.05$. Results. On performing statistical analysis, we found out that in types A-C by Eftekhar classification, the acetabular parameters were changing linearly. Some of them were combined in pairs. For example, the acetabular width increase was accompanied by an inclination increase; however, inclination increased more significantly. The bottom thickness and acetabular depth had an inverse correlation. The diagram for visualization of the changing parameters was drawn, and a pairing table was built. The latter allows creating a formula for any dysplastic acetabulum. A concept of the dysplastic defect was considered separately. Its prevalence rate and linear sizes represent the difference between the location of the rotation center of the femoral head in case of dysplastic hip arthritis and rotation center of the normal hip joint. Conclusions. Deformations of the acetabulum in the developmental dysplasia of the hip reflect the difficulties the surgeon faces during the preoperative planning and implantation. However, understanding of the pathomorphology of this process helps to solve some problems associated with implantation technique, e.g. bottom resection or required bone grafting of the dysplastic defect, and need for an additional preoperative examination in the patients.
\end{abstract}

Keywords: dysplastic hip arthritis; acetabulum; plane roentgen-anthropometry; hip arthroplasty

Modern medicine tends to incorporate elements of globalized approach into the systematization of pathological conditions, while the synthetic processes are reserved for diagnostics and treatment. The above mentioned tendency gave rise to the notions of chronic venous disease (CVD), chronic obstructive pulmonary disease (COPD) etc. [1, 2]. Articular diseases make no exception. There is an opinion that hip arthritis should be divided into central and superolateral forms according to the displacement vector of the femoral head [3]. Each form may have its own causes. However, their end result is similar for both, having the same nature and clinical manifestations.
The principal cause of superolateral form is the dysplastic change of hip joint. It induces the dysplastic hip arthritis, the degenerative-dystrophic condition, characterized by the developing articular tip deformity taking the pattern of acetabular wall defects or CCD (centrumcollum-diaphyseal) angle modification and/or femoral anteversion $[4,5]$. At the moment, there are several classifications of dysplastic hip arthritis [6-9], which might be applied in hip arthroplasty. Crowe's classification is preferable while determining the extent of cranial displacement, as it gives a notion as to the arthroplastic difficulties and necessary manipulations to bring down the center of artificial joint rotation. Hartofilakidis' and

C 2019. The Authors. This is an open access article under the terms of the Creative Commons Attribution 4.0 International License, CC BY, which allows others to freely distribute the published article, with the obligatory reference to the authors of original works and original publication in this journal.

Для корреспонденции: Зуб Татьяна Александровна, кандидат медицинских наук, ассистент кафедры медико-социальной экспертизы и реабилитации факультета последипломного образования, Государственное учреждение «Днепропетровская медицинская академия Министерства здравоохранения Украины», ул. В. Вернадского, 9, г. Днепр, 49044; факс +38 (056) 766-48-10; e-mail: zloy.vra4@gmail.com, контактный телефон +38 (095) 88-15-146.

For correspondence: Tetiana Zub, PhD, Assistant at the Department of medical and social expertise and rehabilitation of the Faculty of postgraduate education, State Institution "Dnipropetrovsk Medical Academy of Health Ministry of Ukraine", Vernadsky st., 9, Dnipro, 49044, Ukraine; fax +38 (056) 766-48-10; e-mail: zloy.vra4@gmail.com, phone +38 (095) 88-15-146.

Full list of author information is available at the end of the article. 
Eftekhar's classifications inform about the acetabular morphological changes. The latter classification, for instance, includes 4 stages and describes acetabular deformations in a somewhat more detailed manner [10].

While there exist various approaches to the dysplastic hip arthritis classification, no one quite covers the initial parameters of acetabular modifications in light of the further arthroplasty, despite their describing the morphological changes attending dysplastic hip arthritis (DHA) [4, 11, 12]. This fact explains the importance of integral methodology of acetabular evaluation in order to compare the obtained results and interpret the preceding acetabular defect modifications, extrapolating them from the arthroplastic outcomes and chances of long-term acetabular component and prosthetic stability maintenance.

The purpose of the study was to evaluate the X-ray parameters of the dysplastic acetabulum and visualize the defects defining the results of the total hip arthroplasty.

\section{Materials and methods}

We've studied the roentgen-anthropometric parameters of 201 dysplastic hips (88\% of them female). For the control group, 70 normal hip acetabula of patients with a unilateral hip arthritis of non-dysplastic genesis were chosen ( $86 \%$ of them female). All of the patients belonging to the main group had an arthroplasty of the damaged joints. In order to classify the patients from the main group, we've used N. S. Eftekhar's classification [7]: Type $A-68$ joints, Type $B-58$, Type $C-63$ and Type $\mathrm{D}-12$ joints.

Acetabular parameters were analyzed according to the plan radiographs of the patients' pelvises with enlargement markers. By their nature, principal roentgenanthropometric parameters whose modifications define acetabulum's dysplastic deformation reflect the final stage of superolateral hip arthritis. It is widely known that with dysplastic hip arthritis acetabulum flattens out, its bottom thickens, and upper tip is skewed due to its contact with a decentered femoral head [4, 13]. This is why we've singled out several roentgen-anthropometric parameters describing the above mentioned modification.

Acetabular width is a line connecting the most cranial and caudal acetabular points, without taking into account ossificate filling its lower sections in case when femoral head has a subluxated posistion. It stands to reason that the acetabular width measured at the plan radiographs does not correspond to the acetabular implant's size in case of dysplastic hip arthritis. However, from the superolateral hip arthritis' morphological perspective, this size this very important.

Acetabular inclination is an angle between the acetabular width and a horizontal line drawn across the lower edge of pelvic teardrop on both sides (horizontal teardrop line).

Acetabular depth is a perpendicular section, drawn to the center of acetabular width, between its initial point and acetabular bottom. When a regular hemispherical implant is used during arthroplasty this parameter would increase by $1 \mathrm{~mm}$ if the cup's diameter increases by $2 \mathrm{~mm}$ (corresponding to one size of implant), according to the geometrical principles.

Acetabular bottom thickness is the same perpendicular section between the acetabular bottom and inner cortical plate of the innominal bone. Thickness includes the ossificate filling the acetabular bottom in response to the hemispherical femoral head's absence.

Acetabular index is an integral parameter reflecting the acetabular spherical nature, calculated as a ratio of acetabular depth to width and described in lobes starting from 1.

Positioning of the acetabular component with restoration of femoral head' rotation center during the pre-op planning leads to appearance of a dysplastic acetabular defect. That one is a section delineated by an upper surface of the cup on the bottom and a sclerosed upper edge of the deformed acetabulum on the medial part. The defect doesn't have a lateral wall. It should be noted that its volume and presence is determined by the implanted cup's position [14]. There are sources mentioning that a certain size of acetabular defect rules out the initial cup's stabilization or promotes the stability's loss in a long-term perspective $[15,16]$. Thus, the acetabular defect should be filled with bone grafts. The defect's volume determining the amount of bone grafts is calculated according to the existing formula during the pre-op planning of the optimal cup insertion; however, the necessary parameters are measured in advance [17].

Statistical analysis was performed with biometric analysis of the licensed Microsoft Excel-2003 ${ }^{\circledR}$ and Statistica v 6.1 (Statsoft Inc., СШA) (serial number AGAR 909 E415822FA). We've measured mean (M), standard deviation (SD) for the regular distribution data, median $(\mathrm{Me}), 25^{\text {th }}$ and $75^{\text {th }}$ quartiles - for the nonregular distribution data. Depending on the type, distribution principle, pair-wise or multiple comparison for the unrelated groups, Student's t-test and nonparametric Mann-Whitney, Kruskal-Wallis tests with mediantest, nonparametric Kendall correlation were used. The difference between values was considered significant if $\mathrm{p}<0.05$.

\section{Results and discussion}

Results of the statistically processed findings are presented in Table 1.

A healthy acetabulum has a nearly hemispherical shape (acetabular index $0,47 \pm 0,04$ ), providing anatomical ground for implanting press-fit hemispherical cups in case of a primary hip arthritis. It should be also noted that the mean linear dimensions of a healthy acetabulum are relatively small, explaining why the cups of $50-56 \mathrm{~mm}$ in diameter are used most often [18]. The smallest applicable unit size allows preserving the greater part of bone tissue and its trabecular structure at the implantation site $[15,19]$. 
In case of dysplastic hip arthritis acetabular shape changes. Its width grows from Type A to Type $\mathrm{C}$ (there is a significant direct correlation, $\mathrm{p} \leq 0,05$ ), which might be attributed to a cranial displacement of femoral head. During childhood and adolescence before the growth plates close, acetabular 'roof' becomes sloped due to an eccentric femoral head pressure. In the adulthood, this excessive pressure may even destroy the acetabular 'roof'. Type D belongs to a separate category, being a complete femoral head dislocation where both acetabulum and head are formed separately. In Type D acetabular width is very small.

Due to the acetabular 'roof' destruction and the uppermost acetabular tip's displacement upwards, its medial inclination angle growth. Furthermore, healthy and dysplastic acetabula have a significantly different inclination even for Type A.

Acetabular depth diminishes with dysplastic hip arthritis' degree by N. S. Eftekhar, while the bottom's thickening increases (there are significant direct and inverse correlations for Types $\mathrm{A}-\mathrm{C}, \mathrm{p} \leq 0,05$; respectively).

Acetabular index also diminishes from Type A to Type C. However with Type D it starts to grow. Thus the acetabulum which has never contained the femoral head has a more spherical shape than the acetabulum affected by dysplastic hip arthritis of Type C.

Based on the mean width, depth, inclination and bottom thickness values, we've created two-dimensional models of the acetabula affected by dysplastic hip arthritis (Fig 1, 2) for all the types by N. S. Eftekhar.

However, the Figures don't represent differences between the acetabular deformation types in a noticeable way. This is why we've decided to calculate a percentage ratio between the normal and modified parameters. The healthy acetabular parameters were set at 1 , while the dysplastic hip arthritis parameters described in lobes starting with 1 . To visualize the obtained results, we've made a radar chart where each of the rays represents one of the parameters (Fig. 3).

\section{Discussion}

As it was mentioned above, the increase of width and inclination is caused by the same process of skewing and destruction of acetabular 'roof'. It may be expected that these parameters are changing in the same way. However, in Type A the increase of width to 1,08 of the healthy acetabulum is associated with the increase of inclination of up to 1,33 times at once. In Types B and C, the difference between the parameters in relation to the healthy ones remains almost the same. In Type D, there is an inverse correlation. Underdeveloped acetabular walls lead to a dramatic increase of inclination paired with extremely narrow acetabular width.

As to the depth and bottom's thickness, these two parameters are also interrelated, as they are adjacent sections of the same line. Furthermore, for the healthy acetabulum and Types A, B and C the sum of their absolute values is practically similar and makes from $34,3 \mathrm{~mm}$ to $35,9 \mathrm{~mm}$. In this way, with one parameter diminished, another one will increase. For the healthy ones, the bottom thickness is more representative, and in Type A it makes 1,27 of the healthy acetabulum. The maximum bottom thickness is observed in Type $\mathrm{C}$, amounting to 1,5 of the healthy acetabulum. The depth is not so significantly modified, which might be attributed to the fact that the absolute value of the normal parameter is more than twice the value of bottom thickness. In Type A, the depth is 0,88 of the healthy acetabulum, while in Type $\mathrm{C}-0,70$. In Type $\mathrm{D}$, the sum of absolute values is only $26,4 \mathrm{~mm}$, while the bottom thickness is 1,4 times the healthy acetabulum's value. The bottom's thickening associated with dysplastic hip arthritis occurs due to the ossificate's filling the bottom up and deepening of bottom to the level of a round ligament's of the femoral head bed is permissible. This phenomenon gave rise to a method of successful acetabular component arthroplasty. Its extreme variety, cotiloplasty, which is considered to be less physiologically grounded, as it results in an excessive medicalization of implant's rotation center and diminishing of hip abductors' strength [20, 21].

In Type A, acetabular index is almost $20 \%$ smaller than the healthy one. Its minimum is observed in Type C, with only 0,6 of the healthy one, while in Type D it reaches 0,7 of the healthy one.

Taking into account the X-ray data, we may suggest the following parameters for the dysplastic acetabular deformation by N. S. Eftekhar (Table 2).

Using this Table, one may describe any dysplastic acetabulum. For instance, the formula describing Type

Table 1. Linear, angular and relative parameters of the healthy

and dysplastic acetabulum

\begin{tabular}{|l|c|c|c|c|c|c|}
\hline & $\begin{array}{c}\text { Acetabular } \\
\text { width, } \mathbf{~ m m}\end{array}$ & $\begin{array}{c}\text { Acetabular } \\
\text { inclination, } \\
\text { degrees }\end{array}$ & $\begin{array}{c}\text { Acetabular } \\
\text { depth, } \mathbf{~ m m}\end{array}$ & $\begin{array}{c}\text { Acetabular } \\
\text { bottom } \\
\text { thickness, } \mathbf{m m}\end{array}$ & $\begin{array}{c}\text { Acetabular } \\
\text { index }\end{array}$ & $\begin{array}{c}\text { Dysplastic } \\
\text { acetabular defect, } \\
\mathbf{c m}^{\mathbf{3}}\end{array}$ \\
\hline Healthy $(\mathrm{n}=70)$ & $50,5 \pm 3,8$ & $43,4 \pm 7,4$ & $24,2 \pm 2,6$ & $11,6 \pm 1,6$ & $0,47 \pm 0,04$ & OTсутствует \\
\hline Type A $(n=68)$ & $54,6[50,0-58,2]$ & $58,2 \pm 5,9$ & $21,2 \pm 3,2$ & $14,7 \pm 3,1$ & $0,39 \pm 0,06$ & $0,23[0,00-0,96]$ \\
\hline Tyре B $(n=58)$ & $56,6 \pm 7,0$ & $61,1 \pm 7,8$ & $19,1 \pm 2,9$ & $15,2 \pm 2,8$ & $0,34 \pm 0,06$ & $1,39 \pm 1,11$ \\
\hline Tyре C $(n=63)$ & $62,9 \pm 8,9$ & $64,6 \pm 6,9$ & $17,1 \pm 4,2$ & $17,3[15,3-20,0]$ & $0,28 \pm 0,07$ & $3,22 \pm 2,07$ \\
\hline Tyре D $(n=12)$ & $32,0 \pm 2,5$ & $68,7 \pm 9,8$ & $10,1 \pm 6,2$ & $16,3 \pm 5,4$ & $0,33 \pm 0,21$ & $4,90 \pm 2,07$ \\
\hline
\end{tabular}

Note: parameters are presented accordingly: $M \pm S D$ for the regular distribution data and $M e$ [ $25^{\text {th }}$ quartile $-75^{\text {th }}$ quartile] for the nonregular distribution data 
B dysplastic hip arthritis would be as follows: width increased by $10 \%$, inclination by $40 \%$, bottom thickness by $30 \%$, depth and index diminished by $20 \%$. A minor increase of width does not affect the location of vertical rotation center for an artificial joint; however, the increased inclination requires a careful cup positioning in order to avoid verticalization [14, 22]. Acetabular sphericity may be recovered by its bottom's resection.

By contrast, the formula describing Type D dysplastic hip arthritis is calculated in the following way: acetabular width reduced by $35 \%$, inclination increased by $60 \%$, depth reduced by $60 \%$, bottom thickness increased by $40 \%$, acetabular index reduced by $30 \%$. It is evident that drilling-out is required as even the smallest acetabular element has extensive geometrical parameters. Drilling-out may be performed by width, as well as by depth (the thickened bottom permitting). Underdeveloped acetabular walls inevitably require the bone grafting of the loaded site (more often at the implant cup's superior pole). One should be careful about the inclination and cup's anteversion because all the acetabular walls are underdeveloped.

It is impossible to determine the ratio of dysplastic defect's volume to the healthy acetabulum, as the defect is absent in the healthy acetabulum (Table 1, Fig. 4).

In Type A, the defect is revealed in $57,8 \%$ of cases, in Type B - in $81,8 \%$ of cases, in Type $\mathrm{C}-$ in $93,6 \%$ of cases, in Type D - in $100 \%$ of cases. The findings reflect the difference between the femoral head's rotation center with dysplastic hip arthritis and rotation

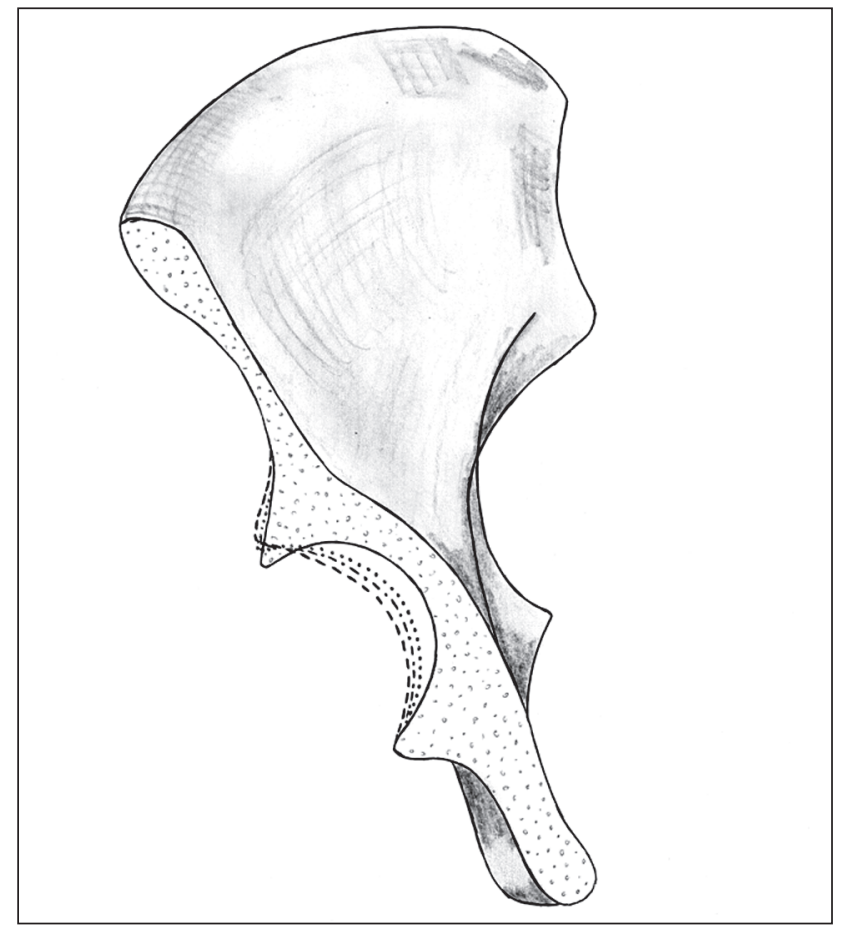

Fig.1. Shape of a healthy acetabulum and the one affected by dysplastic hip arthritis: healthy---, Type A ...., Type B -०-॰-, Type C ----- center of the healthy hip joint. One may find references to the "recovery of true center of rotation" [19, 23, 24], as even despite the dysplasia, normal rotation center is optimal from the biomechanical perspective. This 'recovery' presupposes bringing down and optimal medicalization of artificial joint's center of rotation during cup's insertion $[22,25]$.

\section{Conclusions}

1. With progressing acetabular dysplasia, its deformation parameters are changing unevenly even though they are interconnected. Acetabular inclination increases more noticeably than acetabular width, even though the extent of deformation remains the same. The association between bottom thickness and depth allows the bottom's deepening-out to correct the rotation center of artificial joint.

2. Acetabular index with a complete subluxation is closer to the norm than with dysplastic hip arthritis Type C.

3. Dysplastic defect occurs during the recovery of true center of rotation. Its extent depends on the cranial position of the femoral head before the surgery.

4. The suggested analysis of acetabular evaluation according to the $\mathrm{X}$-ray data allows describing the defect and choosing the optimal implanting technique.

5. Defect evaluation method provides the clear screening parameters of visualization requiring specification by precise diagnostic tools. However, without these parameters it's impossible to evaluate the principal vectors and trends of diagnostic precision procedures.

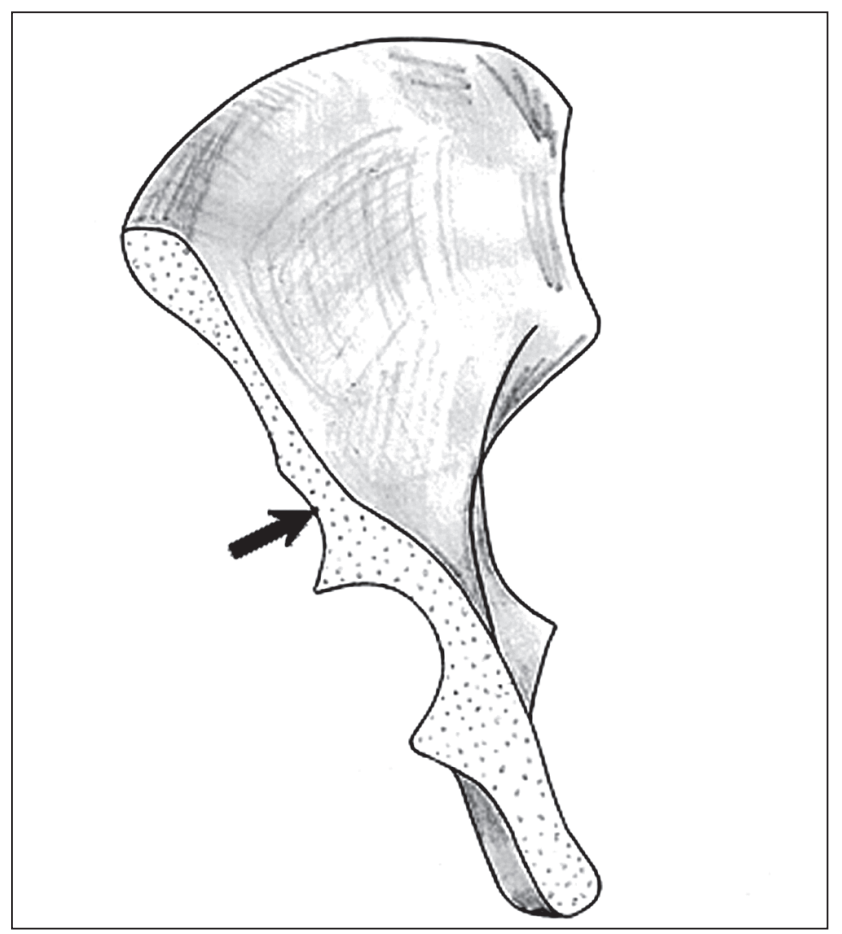

Fig.2. Acetabular shape for dysplastic hip arthritis of Type $D$. The arrow points at the 'false' acetabulum in contact with a femoral head 


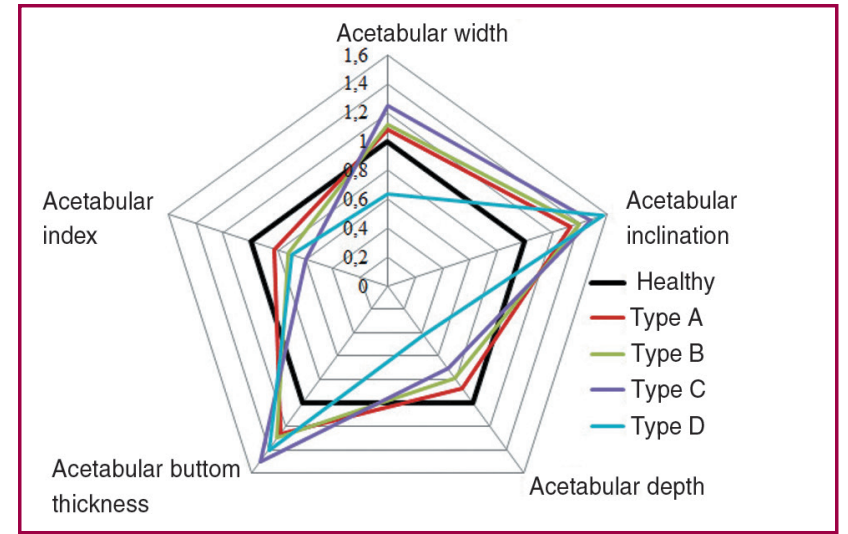

Fig. 3. Morphological changes of healthy acetabulum compared to the one affected by dysplastic hip arthritis

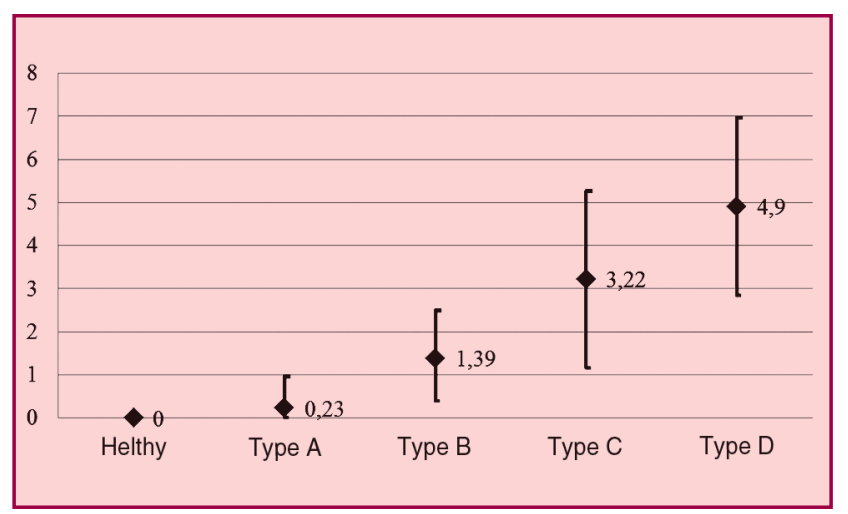

Fig.4. Change of dysplastic defect's volume with dysplastic hip arthritis

Table 2. Parameters of dysplastic acetabulum in light of defect by N.S. Eftekar's classification (norm is set at 1)

\begin{tabular}{|l|c|c|c|c|c|}
\hline \multicolumn{1}{|c|}{ Parameter } & Norm & Type A & Type B & Type C & Type D \\
\hline Acetabular width & 1 & $+0,08(1,08)$ & $+0,12(1,12)$ & $+0,25(1,25)$ & $-0,35(0,65)$ \\
\hline $\begin{array}{l}\text { Acetabular } \\
\text { inclination }\end{array}$ & 1 & $+0,35(1,35)$ & $+0,4(1,4)$ & $+0,5(1,5)$ & $+0,6(1,6)$ \\
\hline Acetabular depth & 1 & $-0,1(0,9)$ & $-0,2(0,8)$ & $-0,3(0,7)$ & $-0,6(0,4)$ \\
\hline $\begin{array}{l}\text { Acetabular bottom } \\
\text { thickness }\end{array}$ & 1 & $+0,25(1,25)$ & $+0,3(1,3)$ & $+0,5(1,5)$ & $+0,4(1,4)$ \\
\hline Acetabular index & 1 & $-0,2(0,8)$ & $-0,3(0,7)$ & $-0,4(0,6)$ & $-0,3(0,7)$ \\
\hline
\end{tabular}

Conflicts of interests. Authors declare the absence of any conflicts of interests and their own financial interest that might be construed to influence the results or interpretation of their manuscript. Authors received no financial compensation and report no sponsorship in the study 'Methods of acetabular defect visualization in dysplastic hip arthritis'.

Information on the authors' individual contributions: O.Ye. Oleynik - concept and study design, writing the article; T.O. Zub - study design, collection and processing of data, writing the article

\section{References}

1. Wittens C, Davies AH, Bækgaard N, et al. Editor's Choice - Management of Chronic Venous Disease: Clinical Practice Guidelines of the European Society for Vascular Surgery (ESVS). Eur J Vasc Endovasc Surg. 2015 Jun;49(6):678-737. https://doi.org/10.1016/j. ejvs.2015.02.007.

2. Vestbo J, Hurd SS, Agustí AG, et al. Global strategy for the diagnosis, management, and prevention of chronic obstructive pulmonary disease: GOLD executive summary. Am J Respir Crit Care Med. 2013 Feb 15;187(4):347-65. https://doi.org/10.1164/rccm.201204-0596PP.

3. Ledingham J, Dawson S, Preston B, Milligan G, Doherty M. Radiographic patterns and associations of osteoarthritis of the hip. Ann Rheum Dis. 1992 Oct;51(10):11116. https://doi.org/10.1136/ard.51.10.1111.
4. Anisimova EA, Yusupov KS, Anisimov DI. Morphology of bone structures of hip joint in normal state and in dysplastic coxarthrosis (review). Saratov Journal of Medical Scientific Research. 2014;10(3):373-377. (in Russian).

5. Postel M. Anatomical abnormalities of the hip. Rev Chir Orthop Reparatrice Appar Mot. 1976 JulAug;62(5):515-8. (in French).

6. Crowe JF, Mani VJ, Ranawat CS. Total hip replacement in congenital dislocation and dysplasia of the hip. $\mathrm{J}$ Bone Joint Surg Am. 1979 Jan;61(1):15-23.

7. Eftekhar NS. Total hip arthroplasty. $7^{\text {th }}$ ed. St Louis: Mosby; 1993.

8. Hartofilakidis G, Karachalios T. Total hip arthroplasty for congenital hip disease. J Bone Joint Surg Am. 2004 Feb;86(2):242-50. https://doi.org/10.2106/00004623200402000-00005.

9. Hartofilakidis G, Stamos K, Ioannidis TT. Low friction arthroplasty for old untreated congenital dislocation of the hip. J Bone and Joint Surg. 1988;70B(2):182-186. https://doi.org/10.1302/0301-620X.70B2.3346284.

10. Zub TO, Loskutov OYe, Loskutov OA. On the classification of dysplastic coxarthrosis in adults. Orthopaedics, Traumatology and Prosthetics. 2010;(2):83-87. https://doi. org/10.15674/0030-59872010283-87. (in Russian).

11. Sharp IK. Acetabular dysplasia: the acetabular angle. J Bone Joint Surg. 1961;43B(2):268-272. https://doi. org/10.1302/0301-620X.43B2.268.

12. Oleynik OYe, Zub TO. An integral analysis of the acetabular parameters for the pathomorphological evalua- 
tion of dysplastic hip arthritis. Morphologia. 2018;12(2):5561. https://doi.org/10.26641/1997- 9665.2018.2.55-61. (in Russian).

13. Korzh AA, Tikhonenkov ES, Andrianov VL, et al. Displasticheskii koksartroz: khirurgicheskaia profilaktika i lechenie [Dysplastic coxarthrosis: surgical prevention and treatment]. Moscow: Meditsina; 1986. 208 p. (in Russian).

14. Loskutov OYe, Oleynik OYe, Zub TO. The features of deformation in dysplastic hip arthritis from the position of hip replacement. Orthopaedics, Traumatology and Prosthetics. 2011;(2):23-28. (in Russian).

15. Inao S, Matsuno T. Cemented total hip arthroplasty with autogenous acetabular bone grafting for hips with developmental dysplasia in adults: the results at a minimum of ten years. J Bone Joint Surg Br. 2000 Apr;82(3):375-7.

16. Tikhilov RM, Shubnyakov II, Mazurenko AV, et al. Experimental substantiation of acetabular component impaction with uncoverage in arthroplasty of patients with severe hip dysplasia. Traumatology and Orthopedics of Russia. 2013;(4):42-51. https://doi.org/10.21823/23112905-2013--4-42-51. (in Russian).

17. Loskutov OYe, Oleynik OYe, Zub TO. The method of estimation of the acetabular dysplastic defect. Litopys of traumatology and orthopedics. 2012;(1-2):70-72. (in Ukrainian).

18. Zeng Y, Wang Y, Zhu Z, Tang T, Dai K, Qiu S. Differences in acetabular morphology related to side and sex in a Chinese population. J Anat. 2012 Mar;220(3):256-62. https://doi.org/10.1111/j.1469-7580.2011.01471.x.

19. Della Valle AG, Padgett DE, Salvati EA. Preoperative planning for primary total hip arthroplasty. J Am Acad Orthop Surg. 2005 Nov;13(7):455-62.
20. Hartofilakidis G, Stamos K, Karachalios T, Ioannidis TT, Zacharakis N. Congenital hip disease in adults. Classification of acetabular deficiencies and operative treatment with acetabuloplasty combined with total hip arthroplasty. J Bone Joint Surg Am. 1996 May;78(5):683-92. https://doi.org/10.2106/00004623-199605000-00007.

21. Dorr LD, Tawakkol S, Moorthy M, Long W, Wan Z. Medial protrusio technique for placement of a porous-coated, hemispherical acetabular component without cement in a total hip arthroplasty in patients who have acetabular dysplasia. J Bone Joint Surg Am. 1999 Jan;81(1):83-92. https://doi.org/10.2106/00004623-199901000-00012.

22. Daines BK, Dennis DA. The importance of acetabular component position in total hip arthroplasty. Orthop Clin North Am. 2012 Nov;43(5):e23-34. https://doi. org/10.1016/j.ocl.2012.08.002.

23. Bonnin MP, Archbold PH, Basiglini L, Fessy MH, Beverland DE. Do we medialise the hip centre of rotation in total hip arthroplasty? Influence of acetabular offset and surgical technique. Hip Int. 2012 Jul-Aug;22(4):371-8. https://doi:10.5301/HIP.2012.9350.

24. Schofer MD, Pressel T, Heyse TJ, Schmitt J, Boudriot U. Radiological determination of the anatomic hip centre from pelvic landmarks. Acta Orthop Belg. 2010 Aug;76(4):479-85.

25. Fukui K, Kaneuji A, Sugimori T, Ichiseki T, Matsumoto T. How far above the true anatomic position can the acetabular cup be placed in total hip arthroplasty? Hip Int. 2013 Mar-Apr;23(2):129-34. https://doi.org/10.5301/ hipint.5000010.

Received 02.06.2019

Revised 23.06.2019

Accepted 15.07.2019

\section{Information about authors}

0.Ye. Oleynik, MD, PhD, Professor at the Department of traumatology, State Institution "Dnipropetrovsk Medical Academy of Health Ministry of Ukraine", Dnipro, Ukraine; ORCID iD: https: //orcid.org/0000-0002-0382-2590.

Tetiana Zub, PhD, Assistant at the Department of medical and social expertise and rehabilitation of the Faculty of postgraduate education, State Institution "Dnipropetrovsk Medical Academy of Health Ministry of Ukraine", Dnipro, Ukraine; ORCID iD: https://orcid.org/0000-0001-8404-0437.

Олійник О.Є., Зуб Т.О.

Державний заклад “Дніпропетровська медична академія Міністерства охорони здоров'я України», м. Дніпро, Україна

\section{Методи візуалізації дефектів кульшової западини при диспластичному коксартрозі}

Резюме. Актуальність. Залежно від напрямку зміщення головки стегнової кістки коксартроз можна поділити на центральну та суперлатеральну форми; у другому випадку основною причиною є диспластичні зміни суглобових кінців кісток, що формують кульшовий суглоб. Наявні класифікації диспластичного коксартрозу мають описовий характер і оцінюють вибірково або форму кульшової западини, або відстань, на яку головка стегнової кістки зміщується в краніальному напрямку, але жодна 3 них не враховує дефекти кульшової западини, викликані дисплазію, або їх вплив на результати оперативного лікування. Мета дослідження - оцінити рентгенантропометричні показники кульшової западини при диспластичному коксартрозі з наступною візуалізацією дефектів, що визначають результати ендопротезування кульшо- вого суглоба. Матеріали та методи. Виконано аналіз основних рентгенантропометричних показників кульшової западини 201 кульшового суглоба з ознаками диспластичного коксартрозу та 70 здорових кульшових суглобів без ознак дисплазії. Вивчено показники ширини, глибини, товщини дна кульшової западини, індекс кульшової западини (відношення глибини до ширини), іiі інклінацію й обсяг диспластичного дефекту. Статистичний аналіз містив розрахунки середніх, відносних величин, медіани, квартилів, непараметричних критеріїв Манна - Уїні, Крускала - Уолліса з медіанним тестом, непараметричної кореляції Кендалла. Різницю між порівнюваними величинами вважали статистично значущою за умови р < 0,05. Результати. Після статистичної обробки визначено, що при дисплазії кульшової западини (ти- 
пи A-C за N.S. Eftekhar) показники змінюються лінійно. Були виділені пари показників, що пов'язані між собою. Так, збільшення ширини кульшової западини відбувається одночасно зі збільшенням іiї інклінації, але збільшення останньої є більш істотним. Товщина дна та глибина кульшової западини, навпаки, мають зворотню кореляцію. Побудовано діаграму, що візуалізує зміни кульшової западини при диспластичному коксартрозі, а також таблицю сполучення, що дозволяє скласти формулу кульшової западини для будь-якого типу диспластичної деформації. Окремо розглянуте поняття диспластичного дефекту кульшової западини. Частота його поширеності та розміри залежать від різниці між положенням центру ротації головки стегнової кістки при диспластичному коксартрозі та центру обертання кульшового суглоба в нормі.
Висновки. Деформації кульшового суглоба при диспластичному коксартрозі відображають труднощі, що виникають перед хірургом у процесі передопераційного планування й виконання ендопротезування кульшового суглоба. Проте розуміння патоморфології цього захворювання дозволяє вирішити низку проблем, що пов'язані з хірургічною технікою імплантації, наприклад, поглиблення дна кульшової западини за рахунок дозованої резекції чи визначення потреби у кістковій пластиці диспластичного дефекту, необхідність виконання додаткових методів обстеження при підготовці пацієнтів цієї категорії до операції.

Ключові слова: диспластичний коксартроз; кульшова западина; площинна рентгенантропометрія; ендопротезування кульшового суглоба

Олейник А.Е., Зуб Т.А.

Государственное учреждение "Днепропетровская медицинская академия Министерства здравоохранения Украины", 2. Днепр, Украина

\section{Методы визуализации дефектов вертлужной впадины при диспластическом коксартрозе}

Резюме. Актуальность. В зависимости от направления смещения головки бедренной кости коксартроз можно разделить на центральную и суперлатеральную формы; во втором случае основной причиной являются диспластические изменения суставных концов костей, формирующих тазобедренный сустав. Имеющиеся классификации диспластического коксартроза имеют описательный характер и оценивают избирательно либо контур вертлужной впадины, либо величину проксимального смещения головки бедренной кости, но ни одна из них не учитывает дефекты вертлужной впадины, вызванные дисплазией, и их влияние на результаты оперативного лечения. Цель исследования - оценить рентгенантропометрические параметры вертлужной впадины при диспластическом коксартрозе с последующей визуализацией дефектов, которые определяют результаты эндопротезирования тазобедренного сустава. Материалы и меmоды. Был проведен анализ основных рентгенантропометрических показателей вертлужной впадины 201 тазобедренного сустава с признаками диспластического коксартроза и 70 здоровых тазобедренных суставов без признаков дисплазии. Изучены показатели ширины, глубины, толщины дна вертлужной впадины, индекс вертлужной впадины (отношение глубины к ширине), ее инклинация и объем диспластического дефекта. Статистический анализ включал расчеты средних, относительных величин, медианы, квартилей, непараметрических критериев Манна - Уитни, Крускала - Уоллиса с медианным тестом, непараметрической корреляции Кендалла. Различия между сравниваемыми величинами считали статистически значимыми при $\mathrm{p}<0,05$. Результаты. После статистической обработки установлено, что при дисплазии вертлужной впадины (типы A-C по
N.S. Eftekhar) изменение ее показателей происходит линейно. При этом были выделены пары показателей, связанных между собой. Так, увеличение ширины вертлужной впадины происходит одновременно с увеличением ее инклинации, но при этом инклинация изменяется более существенно. Толщина дна и глубина вертлужной впадины, наоборот, имеют обратную корреляцию. Произведено построение диаграммы, визуализирующей изменения вертлужной впадины при диспластическом коксартрозе, а также таблицы сопряжения, которая позволяет составить формулу вертлужной впадины для любого типа диспластической деформации. Отдельно рассмотрено понятие диспластического дефекта вертлужной впадины. Частота его встречаемости и размеры отражают разницу между положением центра вращения головки бедренной кости при диспластическом коксартрозе и центром врашения тазобедренного сустава в норме. Выводы. Деформации вертлужной впадины при диспластическом коксартрозе отражают сложности, которые возникают перед хирургом в процессе предоперационного планирования и выполнения операции эндопротезирования тазобедренного сустава. Однако понимание патоморфологии данного заболевания позволяет решить ряд проблем, связанных с хирургической техникой выполнения имплантации, например, углубление дна вертлужной впадины за счет дозированной резекции или определение потребности в костной пластике диспластического дефекта, необходимость выполнения дополнительных методов обследования при подготовке пациентов этой категории к операции.

Ключевые слова: диспластический коксартроз; вертлужная впадина; плоскостная рентгенантропометрия; эндопротезирование тазобедренного сустава 